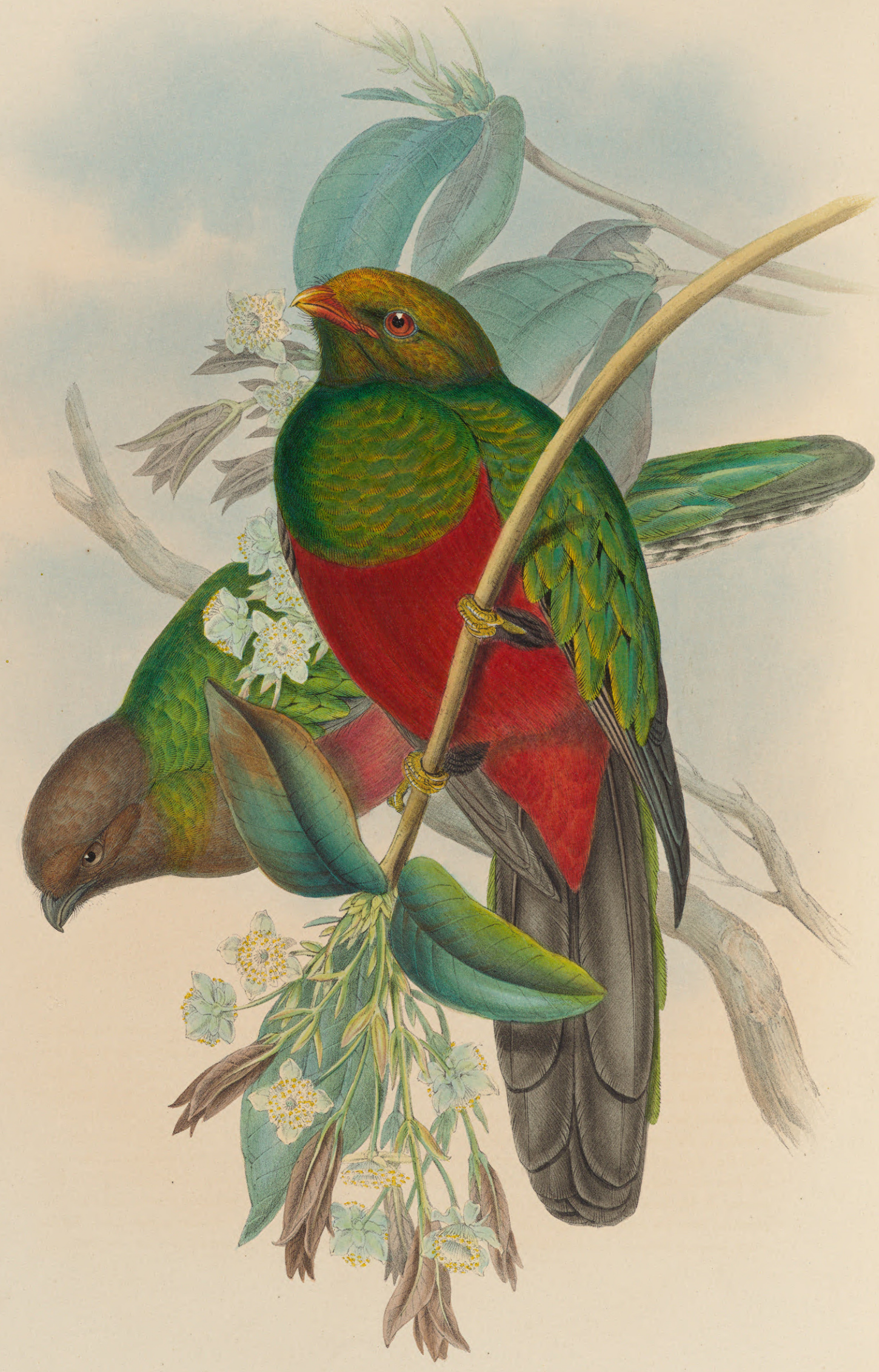




\section{PHAROMACRUS PAVONINUS.}

\section{Red-billed Train-bearer.}

\section{Specific Character.}

Mas. Rostro ad basin miniaceo, ad apicem flavo; caudá nigrá.

Male.-Head and breast glossy green in some specimens, rich golden green in others; wings and the whole of the upper surface rich glossy green; upper tail-coverts green, the two centre ones reaching to the end of the tail, but rarely exceeding it; wings and tail black ; breast and under tail-coverts rich scarlet; feathers of the thighs and tarsi black with green reflections; irides dark red inclining to carmine; feet ochre-yellow; bill carmine at the base and yellow at the tip.

Total length $13 \frac{7}{2}$ inches, bill $1 \frac{1}{4}$, wing $7 \frac{1}{2}$, tail 7 .

Female.-Head, throat, and chest dark greyish brown, tinged with green; upper part of the abdomen dark greyish brown, the lower part and the under tail-coverts deep scarlet; feathers of the thighs and tarsi black with green reflections; shoulders and the whole of the upper surface including the upper tail-coverts, which nearly reach to the end of the tail, rich green; wings brownish black with the outer edges of the feathers buff; tail-feathers black, the two outer on each side obscurely rayed with greyish white ; upper mandible dark brown, under mandible dusky carmine becoming brown at the point; irides brown.

Trogon pavoninus, Spix, Av. Bras., tom. i. p. 47, tab. xxxv.-Steph. Cont. of Shaw's Gen. Zool., vol. xiv. part 1, p. 219.-Gould, Proc. of Zool. Soc. 1833, p. 107, 1835, p. 29, \& 1836, p. 12.-Id. Mon. of Trog., pl. 23.

Calurus pavoninus, Swains. Class. of Birds, vol. ii. p. 338.-Gray, Gen. of Birds, vol. i. p. 71, Calurus, sp. 2.-Bonap. Consp. Gen. Av., tom. i. p. 293, Calurus, sp. 2.-Burm. Syst. Uebers. Th. Bras., tom. ii. p. 273, \& ibid. note sp. 3.

Tanypeplus pavoninus, Cab. et Heine, Mus. Hein., Theil iv. p. 205.

Pharomacrus pavoninus, Sclat. and Salv. Proc. of Zool. Soc. 1867, p. 583.

IF ornithologists will examine and compare my figures of the various species of this truly beautiful section of the Trogonida, they will perceive at a glance that the characters of each are so clearly defined that but little attention will be required to distinguish one from another. The bird here represented is the only species of the form that has yet been discovered with a red bill; if, then, this peculiarity be kept in view, and the uniform brownish-black colouring of the tail be remembered, the bird will be readily recognized. Its native country is the interior of Brazil, where it inhabits most, if not all, the great primæval forests bordering the rivers of that extensive region, but more particularly those which flow into the mighty Amazon. Spix was the first who made us acquainted with this fine bird by his figure of it on the thirty-fifth Plate of the first volume of his work on the Birds of Brazil. The late Jolnn Natterer brought specimens with him when he returned from his sojourn of eighteen years in the same country, kindly leaving with me a male and a female when passing through London en route to Vienna. He at the same time informed me that he had had 
frequent opportunities of observing the bird in a state of nature among the great woods bordering upon the upper parts of the Amazon and the Rio Negro, where it is only seen among the highest branches. Since that period examples have been brought to England by Mr. Wallace; and I possess a beautiful specimen obtained by Mr. Hauxwell at Chamicuros. Upon examining the contents of the stomach, Mr. Natterer almost invariably found it to consist of the fruit of a certain species of palm ; he therefore concluded that this, together with various berries and stoned fruits, forms its subsistence. It arrives in the localities above mentioned when its favourite fruit is ripe; and when the trees no longer yield an adequate supply retires again to other districts.

To Mr. Wallace I am indebted for the following notes, which cannot fail to be of interest to all who admire this fine family of birds :-The Pharomacrus pavoninus "inhabits the virgin forests of the higher and dry lands, and is never seen in low woods or among the trees growing on the flooded grounds; but it sometimes visits the plantations to feed on fruit, particularly the soft berries, about the size of currants, of the different species of Melastoma, the juice of which imparts a purple hue to their stomachs. These fruits are always taken when the bird is on the wing. The bird usually sits quietly among the branches until hunger impels it to dash out, whirl round the tree, and seize its food in its passage; it likewise feeds on insects, which are also taken on the wing, the bird darting after them and returning to the same branch in the manner of a Flycatcher. The cry of this species is very peculiar, and different from that of the other Amazonian Trogons ; it consists of two notes sufficiently loud to be heard a long way off. The Indians ascertain the whereabouts of the bird by imitating this cry, which it immediately answers. On ascending the Amazon the bird was first noticed about the mouth of the Rio Negro, and became more plentiful on the upper part of that river; it was actively engaged in the search after insects about sunset, but was not seen to be thus engaged after darkness had set in."

The Plate represents the two sexes, of the natural size. The Plant is the Eugenia Brasilensis. 


\section{$2 \mathrm{BHL}$ Biodiversity Heritage Library}

Gould, John. 1869. "Red-billed Train-bearer, Pharomacrus pavoninus." $A$ monograph of the Trogonidce or trogons 2, -. https://doi.org/10.5962/p.323625.

View This Item Online: https://www.biodiversitylibrary.org/item/264437

DOI: https://doi.org/10.5962/p.323625

Permalink: https://www.biodiversitylibrary.org/partpdf/323625

\section{Holding Institution}

Harvard University, Museum of Comparative Zoology, Ernst Mayr Library

\section{Sponsored by}

Harvard University, Museum of Comparative Zoology, Ernst Mayr Library

\section{Copyright \& Reuse}

Copyright Status: Public domain. The BHL considers that this work is no longer under copyright protection.

This document was created from content at the Biodiversity Heritage Library, the world's largest open access digital library for biodiversity literature and archives. Visit BHL at https://www.biodiversitylibrary.org. 